\title{
MANAGEMENT OF ACCELERATED RELIABILITY TESTING
}

\author{
Sebastian Marian Zaharia, Ionel Martinescu
}

Original scientific paper

The concept of management is found in every activity from the program of accelerated reliability tests for industrial products, starting from the planning, the realization and the statistical processing of the results. Accelerated Reliability Testing (ART) is an experiment in which: the physics of degradation mechanism is similar to the mechanism in the real operation using given criteria; the measurement of reliability has a high correlation with these respective measurements in the real operation using given criteria. An ART is an aging degradation of industrial products to produce normal failure by operating at stress levels much higher than would be expected in normal use. Taking into account the aspects regarding the statistical processing of experimental data, we determined the main reliability parameters, which in turn determine the main characteristics regarding the performance and the warranty period of the product.

Keywords: ART; life cycle; reliability management; statistical processing

\section{Upravljanje ubrzanim ispitivanjem pouzdanosti}

Izvorni znanstveni članak

Pojam upravljanja nalazi se u svakoj aktivnosti iz programa ubrzanog ispitivanja pouzdanosti za industrijske proizvode, počevši od planiranja, realizacije $i$ statističke obrade podataka. Ubrzano ispitivanje pouzdanosti (Accelerated Reliability Testing - ART) je eksperiment u kojemu: fizika mehanizma degradacije slična je mehanizmu u stvarnom radu uz primjenu danih kriterija; mjerenje pouzdanosti u velikoj je korelaciji s takvim mjerenjima u stvarnom radu uz primjenu danih kriterija. ART je degradacija industrijskih proizvoda zbog starenja koja dovodi do normalnog kvara kod rada na razinama naprezanja mnogo višim nego što bi se pri normalnoj uporabi moglo očekivati. Uzimajući u obzir aspekte u odnosu na statističku obradu eksperimentalnih podataka, odredili smo glavne parametre pouzdanosti, koji zatim određuju glavne karakteristike u odnosu na performansu i vrijeme proizvoda pod garancijom.

Ključne riječi: statistička obrada; ubrzano ispitivanje pouzdanosti; upravljanje pouzdanošću; životni krug

\section{Introduction}

Since the increase of the products' technical and complexity level, as well as the increase of socioeconomic implications of their use, certain qualitative characteristics have gained a special importance, being primarily followed during the products' life cycle. Although reliability is a stand-alone concept, between the concepts of reliability and quality there is a strong connection.

If quality represents the entirety of a product's properties that make it adequate for use according to its destination, in turn reliability is the product's capacity to maintain its quality throughout its use period. In other words, reliability is the product's quality extended in time. If in the past the unlimited operation of the products was considered, nowadays, in accordance with the requirements of the accelerated scientific and technical progress and of maximum efficiency, the conception and realization of these products is made considering their use on determined time periods, at an optimum level of performance. Depending on the modality in which a certain value of reliability, at a specific time, interests us, there is a classification of different types of reliability (Fig. 1).

Taking into account the main requirement of reliability - the increase in the performances of industrial products, in direct correlation with the followed purpose it is necessary to confer reliability tests a significant importance. The main reliability parameter pursued during the tests will be the mean time between failures, knowing that, based on existing relations between reliability parameters; these can be easily deduced from one another. The estimated values of reliability parameters are determined by statistical processing of the experimental data obtained from tests on samples [1].

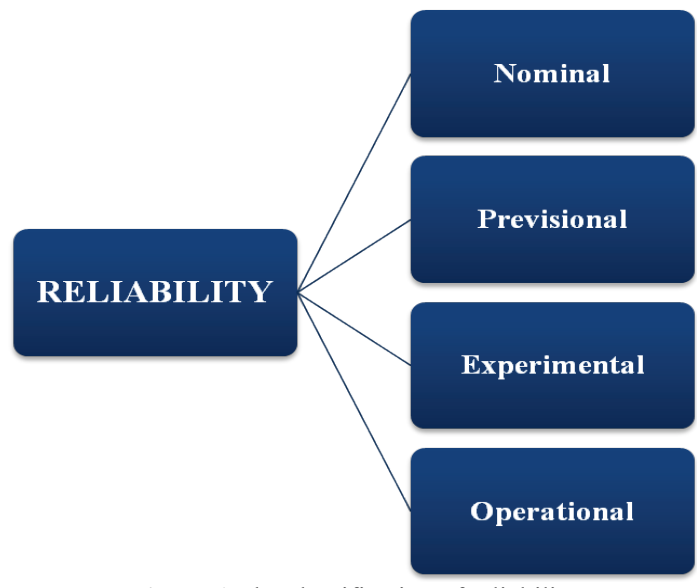

Figure 1 The classification of reliability

The long duration of carrying out the complete reliability tests is the effective durability of the product that fails the last. There are two major disadvantages of these types of experiments:

- The high cost, because the products being unrepairable will all be lost at the end of the testing;

- The long testing duration - in the cases where the products have a long durability using the normal regime testing.

To reduce these disadvantages, we proceed to the acceleration of the experiment, meaning the acceleration of the failure process by enhancing experimental conditions and the introduction of additional stress factors. The necessity for acceleration is motivated by the 
following argument: the more reliable a product is, the more difficult it is to evaluate quantitatively its reliability. Some tests, in normal conditions, can last up to months or even years; assuming that these kinds of tests can be executed on a very large time scale, the rapid progress of technology may lead to a situation where we would estimate the reliability of a product already morally obsolete. The logical solution is in these cases to increase the level of stress for different factors that act on the performances of the tested product and then to evaluate the obtained reliability for normal operating conditions [2].

Integrated global solutions for many engineering problems in quality, safety, reliability, durability, maintainability were not available in the past. One of the basic reasons for this design deficiency was the inability to solve a fundamentally important problem - accelerated reliability testing (ART). Accelerated reliability testing provides an integrated solution that will positively influence product development time, cost, quality, design and effective product. Accelerated reliability test began many years ago with the development of the necessary methodology and equipment. Development continues in the future. As the knowledge about life and laws of nature evolves, the requirements for products and technologies have also increased in scope. Often, accelerated reliability testing methods and equipment that were satisfactory in the past are no longer satisfactory today. Those that are good today will not satisfy the requirements of producers and users in the future. Accelerated testing methods [3] can be either qualitative or quantitative (Fig. 2).

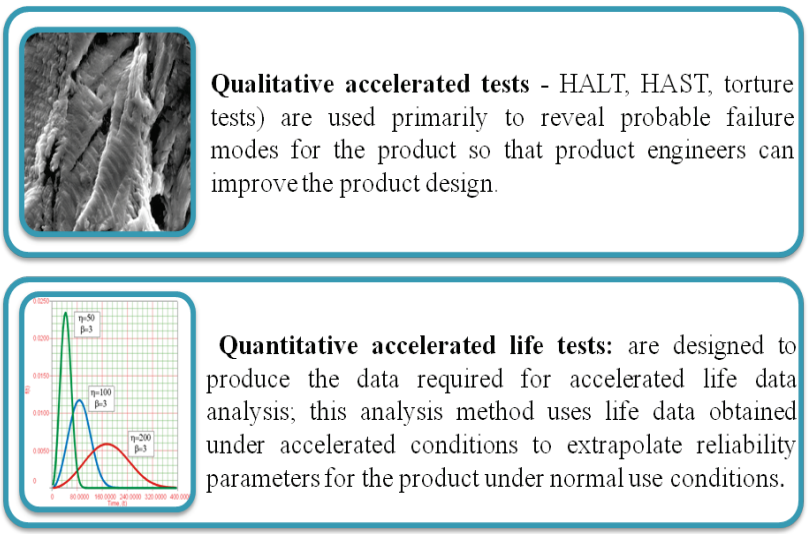

Figure 2 The classification of the accelerated tests

Accelerated reliability testing is a methodology comprised of a series of test methods, which can shorten the service life of products or significantly increase the rate at which their properties degrade. Accelerated reliability tests are performed on materials, components, or entire systems, under conditions of accelerated stresses compared to normal operating parameters. Accelerated reliability test data, when properly analysed and modelled, can provide valuable information that could be used to project a product's long-term performance and service life under normal operating conditions. The information derived from this process may also be incorporated into one or more aspects of developing or fielding a product, thereby making some fundamental improvement in product quality, life, cost, or other desired characteristic. The following presents three basic approaches for the practical use of accelerated reliability testing as shown in Fig. 3 [4].

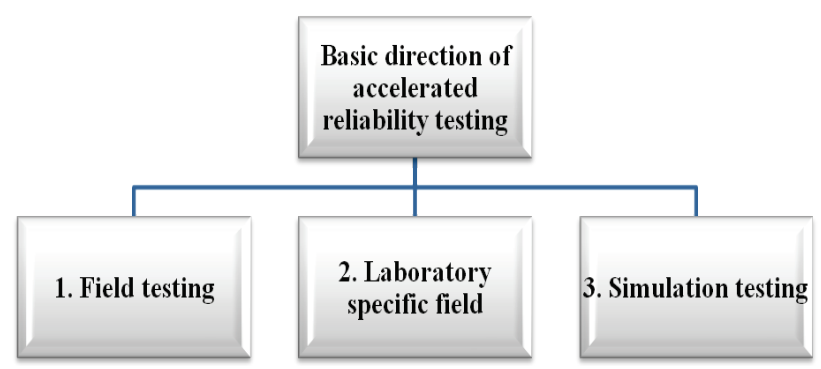

Figure 3 The main directions of accelerated reliability testing

The first approach is special testing with more intensive usage than under a normal use. The second approach is to use accelerated stress testing (AST). The third approach relies on using a computer (software) simulation or analytical/statistical methods. Computer simulations have become a useful part of the mathematical modelling of many natural systems in physics and engineering.

Overstressing, the most commonly used method of acceleration, consists of subjecting some products to stress levels more intense than those from normal conditions of use. The stresses applied in an accelerated test should stimulate the failure of the product in normal use also. Such stresses include environmental, electrical, mechanical and chemical stimuli, namely: temperature, humidity, subjecting to thermal cycle, radiation, tension, electric current, vibrations and mechanical stress. The stresses may be applied following several patterns, which include: the constant stress; the gradual stress; the progressive stress; the cyclic stress; the random stress.

Poor accelerated test plans waste time, effort and money and may not even yield the desired information. Before starting an accelerated test, which is sometimes an expensive and difficult endeavour, it is advisable to have a plan that helps in accurately estimating reliability at operating conditions while minimizing test time and costs. A test plan should be used to decide on the appropriate stress levels for each stress type and the number of test units that need to be allocated to the different stress levels - for each combination of stress types/levels. There are different types of ALT plans in use, which include subjective, traditional, best traditional, and statistically optimum and compromise plans [5].

Accelerated models are useful for translating reliability parameters across different stress levels. There are models for single sources of stress and multiple sources of stress. Proper understanding and use of these models can greatly improve the efficiency of accelerated reliability testing. Acceleration models can be classified into the following three types: physical models; quasiphysical models; empirical models. Among the most important acceleration models we can mention the following [6]: Arrhenius, Eyring, Inverse Power Law; Life - Thermal, Life - Voltage, Life - Vibration, Life Humidity, Temperature - Humidity.

Accelerated reliability testing is used in electronics, (resistors, lasers, displays, electronic bounds, circuit breakers, relays, cells and batteries) in the study of metals and composite materials [7], but also for certain 
components [8] and mechanical assemblies (automobile parts, hydraulic components, bearings) [9], renewable energy (wind turbine blades) $[10 \div 13]$. In aerospace industry, the accelerated reliability testing is used to test certain components: the engine, the oil pumps, on board electronic equipment [14] and stiffening components spar wing [15].

The implementation of accelerated reliability tests in the aerospace is necessary, because the fatigue tests [16, 17] can have the operating time of millions of cycles until the failing of components occurs (the helicopter blade, the supple platinum [18], command rods, the wing and the landing gear). That is the reason why the accelerated reliability tests represent a method by which the testing time of components from the aerospace field is shortened and thus leading to optimizing of the testing system.

The general management process of defining the reliability program, of organizing, control and implementation of the product is part of the reliability management. The reliability management has several roles and relations that are not covered by a contractual agreement between supplier and client. As every product has during its lifecycle six basic phases (conception and definition, design, development, manufacture, use and end of life), the management and the engineering have to fulfil specific tasks during these phases. The implementation of accelerated reliability tests in the life cycle of the products is a more and more used instrument by the big companies that require products of a higher quality and reliability, in a shorter time period. Fig. 4 represents the life cycle of a product and the accelerated tests are realized in the second phase.

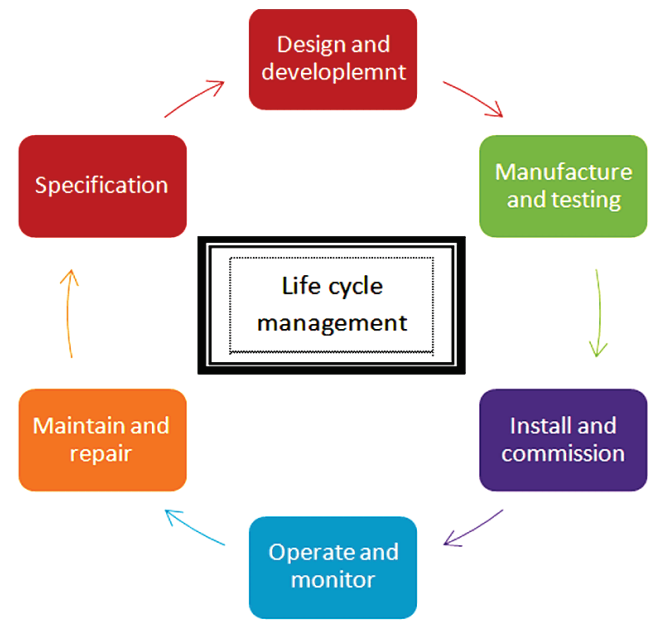

Figure 4 Life cycle management

As a result of the critical study above on the accelerated reliability testing, the goal of the paper becomes evident, which is: the theoretical and experimental study regarding the management of accelerated reliability tests for a product from the field of aviation (blades from the structure of Alouette helicopter), in order to reduce the testing time and obviously of the material costs related to this kind of tests.

\section{Material and methods}

The type of accelerated test that will be used has a direct economic impact, because during the accelerated tests the following intervenes: the cost of the unit of the tested product; the total cost of the experiment; the amount of time necessary for the testing and the analysis of data. So, the selection of a certain type of test is a managerial decision that has to be taken by the responsible authority in the field. The management of accelerated reliability tests consists of applying the knowledge, the capacities, the instruments and specific techniques for the activities of an accelerated test, which have defined objectives, purposes and requirements, concerning time, costs, quality, reliability and performance parameters, activities which are considered important and adequate for financing. The time, the cost, the quality, the reliability and the performances are constraints for an accelerated reliability test.

\subsection{Test bench description}

The experimental stand allows the introduction of stresses according to the blade specimen, as follows: the axial force through an axial cable, chained by a fitting; the dynamic bending force of feathering, in the form of a controlled arrow at the end of the blade, with the help of an eccentric; the dynamic bending force of deflection is modified using rods that make the connection with the strained blade. Basically, the testing bench (Fig. 5) is made of 7 distinct parts:

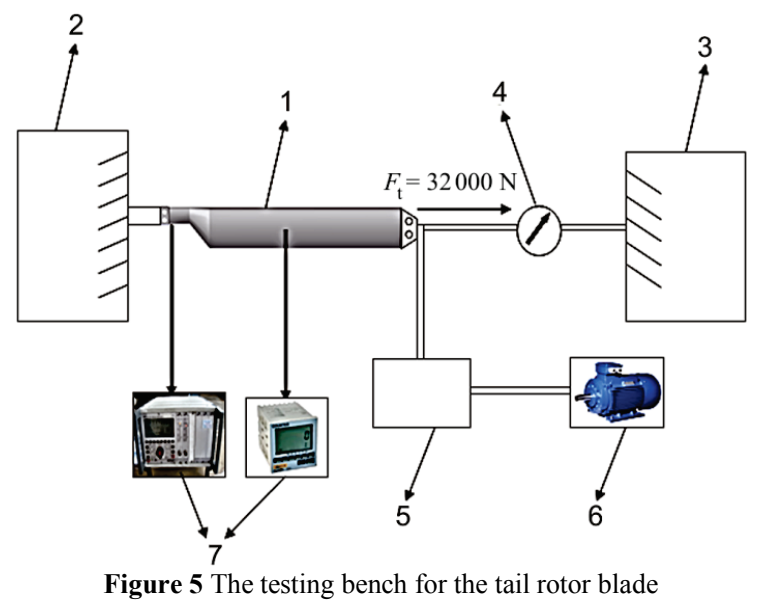

1. The blade of the tail rotor in the structure of the Alouette helicopter.

Before the accelerated testing model was elaborated, we realized a constructive and functional study on the rotor and the blades of the Alouette helicopter. The tail rotor compensates the torque couple generated by the main rotor and has the role of controlling the helicopter on its rotation axis. In the structure of the tail rotor there are 3 blades. The loading of a helicopter blade results from the movements that it executes. During its rotation, the helicopter blade is first subjected to a constant axial force. Due to the periodic aerodynamic forces, of lift and of forward resistance [19], the blade makes two lateral motions: one in the plane of rotation, called the lagging motion, and the second one in the vertical plane, called the feathering motion.

2. The blade's fastening device

This has the role to allow the clamping of the blade similar to that on the helicopter and its rotation around its 
longitudinal axis, in order to realize the specified step angle.

3. The blade's straining device

The main functions of this device are to introduce the axial force in the blade, to measure this force and to cancel it instantaneously in the moment when fissures occur in the blade. The straining of the blade is made with a cable, stretched by a screw with a square thread with a fine step.

4. The dynamometer

Transforms the mechanical size into electrical size and is connected to data acquisition equipment and that in turn is connected to a computer. Using a data acquisition program, the axial force is quantified and indicated on the computer screen. The cable passes over an eccentric roll that in turn is kept in a maximum position by a pneumatic engine. The dynamometer is fitted with strain gauges and connected by an analogical interface with a computer that uses an acquisition program of the value of the axial force from the blade.

5. The device to introduce the bending forces.

In order to apply at the end of the blade a force that gives the momentum in enclosure, this device takes over the rotation motion from the engine-reducing gear block. The rotation motion is transmitted to a bearing fixed on a metallic table, a bearing which supports the axle of the eccentric and the connecting rod's button. The eccentric is fitted with an adjusting system of the eccentric's value and, implicitly, of the arrow at the end of the blade. From the eccentric, the motion is transmitted to the connecting rod, which also transmits the motion to a mechanism that takes over also the effect of the blade's axial stretching and transmits it at the end of the blade.

6 . The energy system

Is divided into two groups: one is made up of an electric engine with two revolutions and a revolution reducing gear that provides the mechanical energy to introduce the alternative force in the blade and the other one consists of two compressors that provide the pneumatic energy necessary for the unlocking system of the traction cable.

7. The electronic equipment

The Hottinger MC 55 data acquisition equipment with 6 channels is used to determine the size of the specific deformations of the blade in different sections, using the strain gauges. Another role of the electronic equipment is to count the number of the blade's stress cycles (the mean number of cycles is $10^{5} \div 10^{7}$ ).

\subsection{Methods and conditions of accelerated reliability testing of the tail rotor blade}

The rotor blades are subjected to two types of fatigue tests: total tests; partial tests. The total tests: represent those tests where the blade is subjected entirely to a fatigue loading regime that is as close as possible to that of real conditions. Such tests are realized usually with the help of special installations, named testing towers. Such a tower allows the assembling of the blades in similar conditions with those in normal use and afterwards their entrainment in the rotation motion provided by the nominal regime of operation. The advantage of the testing towers is the fact that the distribution of the axial (centrifugal) forces along the blade is the same with that in exploitation.

The partial tests: represent those tests where the attention is concentrated on a certain element or part from the assembly of the blade or rotor. To this effect, we can apply on the blade a constant axial force, which, although it does not represent the real force from the blade, has, however, the attribute of being equal in value with the real force. Thus, the testing of the blade at forces which occur during rotation can be realized on a static bench.

The lateral forces that induce the bending of the blade come from aerodynamic and inertia forces having a complex distribution. In the research of the blade, we put a special emphasis on the fixing in the rotor's hub. We can estimate, based on an equivalence principle, that the bending momentum in the fixing section is the one applied through the testing bench, equal to that in real use. The same principle applies to the lagging motion, as well as to the feathering motion.

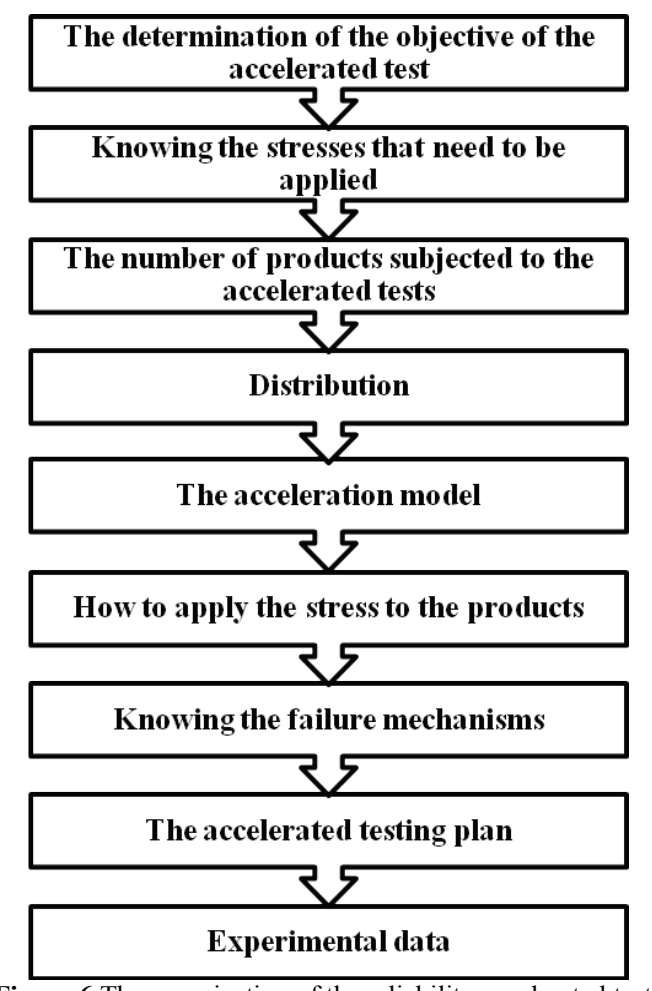

Figure 6 The organization of the reliability accelerated tests

Next we describe the necessary stages for the preparing of accelerated reliability tests (Fig. 6):

a. The determination of the objective of the accelerated test: for the analysed case study we will realize quantitative accelerated tests.

b. Knowing the stresses that need to be applied: the main degradation factor in the case of the blade testing is the bending force to lagging that has in normal testing conditions the value of $800 \mathrm{~N}$ and in accelerated regime that of $1400 \mathrm{~N}$; the bending force to feathering is $300 \mathrm{~N}$; the axial force is $32000 \mathrm{~N}$.

c. The number of products subjected to the accelerated tests: for the accelerated testing of the blades we use 18 blades.

d. The distribution: Weibull. This distribution is very well suited to research regarding the tearing of materials and especially the fatigue of materials [20]. 
e. The acceleration model: Inverse Power Law.

f. How to apply the stress to the products: in the case of the blades' accelerated testing is constant.

g. Knowing the failure mechanisms which will be considered: in the case of the blades' accelerated testing the failure mechanism is a mechanical one - the fatigue for the accelerated tests on the Alouette helicopter blade.

h. The accelerated testing plan: for the blades' accelerated testing we used 3 level best compromise plans.

The testing plan was developed using the ALTA 7 software program, where the above determined parameters have been introduced. In the follow-up of the design of the experiments, an optimum testing report is generated, where there are specified the levels of accelerated testing at which it is indicated to test the helicopter blades, as well as the number of blades tested for every stress level (Tab. 1).

Table 1 The results of the testing plan

\begin{tabular}{|l|c|c|c|}
\hline & $\begin{array}{c}\text { Stress level, } \\
\mathrm{N}\end{array}$ & $\begin{array}{c}\text { Portion } \\
\text { units }\end{array}$ & $\begin{array}{c}\text { Units } \\
\text { on test }\end{array}$ \\
\hline Low stress level & 900 & 0,33 & 6 \\
\hline Middle stress level & 1100 & 0,40 & 7 \\
\hline High stress level & 1400 & 0,27 & 5 \\
\hline
\end{tabular}

The data resulted in the follow-up of the design of the accelerated tests are the following: the first level of acceleration is $900 \mathrm{~N}$, at which 6 blades are tested; the second level of acceleration is $1100 \mathrm{~N}$, at which 7 blades are tested; the third level of acceleration is $1400 \mathrm{~N}$, at which 5 blades are tested.

\subsection{The acquisition of the experimental data}

The accelerated testing to fatigue of the helicopter blades implies their subjection to oscillating stresses, with determined frequency and amplitude, until the occurrence of fissures in the enclosure plane. The realization of this stress is made using the experimental installation, which allows the generation in the investigated section - the neck of the blade's spar of the imposed forces.

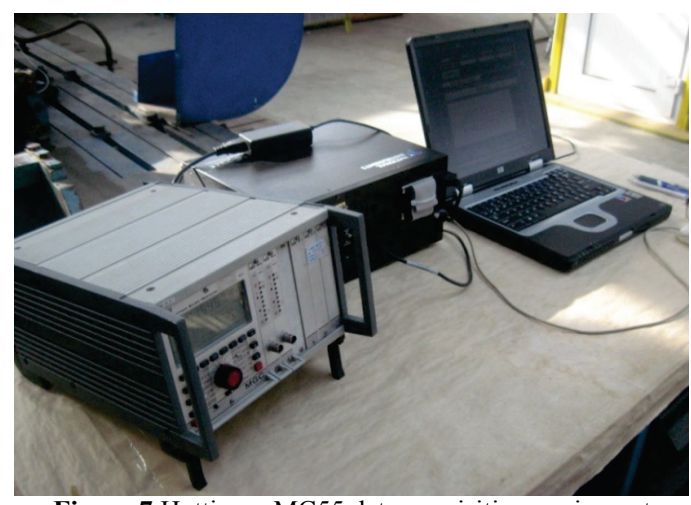

Figure 7 Hottinger MC55 data acquisition equipment

The equipment used in the acquisition of the data resulting from the blade's accelerated tests is composed of the following: Hottinger MC55 data acquisition equipment with 6 channels (Fig. 7); Dynamometer fitted with strain gauges and connected through an analogical interface with a computer, which uses an acquisition program of the value of the axial force from the blade (the imposed value $3200 \mathrm{~N}$ ); Strain gauges; Cycle counter.

Fig. 8 presents a helicopter blade that has in the area of the spar's neck Strain gauges mounted: 2 for the lagging motion and 2 for the feathering motion.

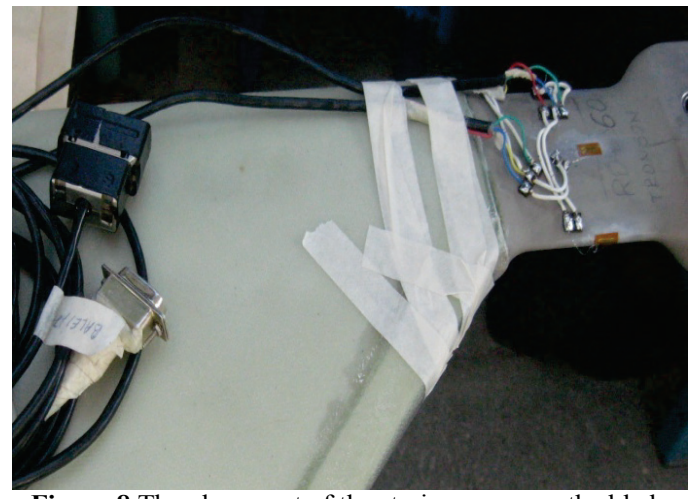

Figure 8 The placement of the strain gauges on the blade

\section{Results and discussion}

The results obtained at the accelerated testing of the tail rotor blades from the structure of the Alouette helicopter for the three levels of accelerated stress (the bending force at the lagging motion $900 \mathrm{~N}, 1100 \mathrm{~N}, 1400$ N) are presented in Tab. 2.

Table 2 The number of cycles until failure corresponding to the bending force at lagging

\begin{tabular}{|c|c|c|c|c|}
\hline No. & $\begin{array}{l}\text { The number } \\
\text { of cycles to } \\
\text { failure }\end{array}$ & $\begin{array}{l}\text { Bending force } \\
\text { at lagging, } \\
\mathrm{N}\end{array}$ & $\begin{array}{l}\text { Bending force } \\
\text { at feathering, } \\
\mathrm{N}\end{array}$ & $\begin{array}{c}\text { Axial } \\
\text { force, } \\
\mathrm{N} \\
\end{array}$ \\
\hline 1 & 640000 & 900 & 300 & 32000 \\
\hline 2 & 687534 & 900 & 300 & 32000 \\
\hline 3 & 710000 & 900 & 300 & 32000 \\
\hline 4 & 740876 & 900 & 300 & 32000 \\
\hline 5 & 756544 & 900 & 300 & 32000 \\
\hline 6 & 764987 & 900 & 300 & 32000 \\
\hline 7 & 300096 & 1100 & 300 & 32000 \\
\hline 8 & 320089 & 1100 & 300 & 32000 \\
\hline 9 & 357899 & 1100 & 300 & 32000 \\
\hline 10 & 404978 & 1100 & 300 & 32000 \\
\hline 11 & 438877 & 1100 & 300 & 32000 \\
\hline 12 & 488987 & 1100 & 300 & 32000 \\
\hline 13 & 534000 & 1100 & 300 & 32000 \\
\hline 14 & 110356 & 1400 & 300 & 32000 \\
\hline 15 & 148755 & 1400 & 300 & 32000 \\
\hline 16 & 166723 & 1400 & 300 & 32000 \\
\hline 17 & 205000 & 1400 & 300 & 32000 \\
\hline 18 & 230545 & 1400 & 300 & 32000 \\
\hline
\end{tabular}

For the results obtained from the accelerated life testing of the blades for the 3 levels of accelerated stress we verified the hypothesis that the distribution law of the number of cycles until failure is Weibull. The Kolmogorov-Smirnov test is one of the most useful and general nonparametric methods for comparing two samples, as it is sensitive to differences in both location and shape of the empirical cumulative distribution functions of the two samples. For this verification, we measured the spacing between empirical distribution function of the sample and the cumulative distribution function of the reference distribution. We compared these results with a level of confidence of the Kolmogorov - 
Smirnov test. Following the statistical processing of the experimental data for the 3 levels of stress the Weibull distribution was accepted. For the calculus of the mean number of cycles to failure and of the reliability parameters under normal testing conditions $(F=800 \mathrm{~N})$ for the blades from the structure of Alouette helicopter, the experimental data resulting from accelerated conditions have been processed using the ALTA7 software. We calculated the three parameters corresponding to the IPL-Weibull model using the maximum likelihood estimation method for the data from the accelerated regime introduced in the ALTA7 software.
The following values of parameters resulted: $\beta=5,979 ; k$ $=1,939 \mathrm{E}-15 ; n=2,989$. The results obtained from accelerated reliability tests are then statistically analysed and extrapolated to obtain estimates of life expectancy under normal conditions. The main purpose of the accelerated tests is to determine the most important reliability parameters in normal use conditions: the mean operation time; the reliability/unreliability function; the failure rate; the probability density. These parameters have been determined using the relations specific to the IPL - Weibull model and are described in Tab. 3.

Table 3 The correlation between the number of cycles until failure and the reliability parameters

\begin{tabular}{|c|c|c|c|c|c|}
\hline No. & $\begin{array}{l}\text { The number of cycles to } \\
\text { failure }\end{array}$ & $\begin{array}{c}\text { Reliability } \\
R(t)\end{array}$ & $\begin{array}{c}\text { Unreliability } \\
F(t)\end{array}$ & $\begin{array}{l}\text { Failure rate } \\
z(t)\end{array}$ & $\begin{array}{c}\text { Probability density } \\
f(t)\end{array}$ \\
\hline 1 & 587936 & 0,9622338 & 0,0377662 & 0,00000027 & 0,00000026 \\
\hline 2 & 777499 & 0,9084943 & 0,0915057 & 0,00000107 & 0,00000093 \\
\hline 3 & 792512 & 0,8541903 & 0,1458097 & 0,00000118 & 0,00000101 \\
\hline 4 & 829298 & 0,7997618 & 0,2002382 & 0,00000148 & 0,00000120 \\
\hline 5 & 888238 & 0,7452878 & 0,2547122 & 0,00000208 & 0,00000153 \\
\hline 6 & 910111 & 0,6907928 & 0,3092072 & 0,00000234 & 0,00000164 \\
\hline 7 & 927257 & 0,6362864 & 0,3637136 & 0,00000257 & 0,00000173 \\
\hline 8 & 977707 & 0,5817738 & 0,4182262 & 0,00000335 & 0,00000194 \\
\hline 9 & 1009655 & 0,5272583 & 0,4727417 & 0,00000393 & 0,00000202 \\
\hline 10 & 1049231 & 0,4727420 & 0,5272580 & 0,00000476 & 0,00000206 \\
\hline 11 & 1053562 & 0,4182264 & 0,5817736 & 0,00000486 & 0,00000206 \\
\hline 12 & 1075843 & 0,3637137 & 0,6362863 & 0,00000539 & 0,00000204 \\
\hline 13 & 1087849 & 0,3092075 & 0,6907925 & 0,00000570 & 0,00000202 \\
\hline 14 & 1092164 & 0,2547122 & 0,7452878 & 0,00000581 & 0,00000201 \\
\hline 15 & 1137058 & 0,2002382 & 0,7997618 & 0,00000710 & 0,00000184 \\
\hline 16 & 1228258 & 0,1458097 & 0,8541903 & 0,00001043 & 0,00000122 \\
\hline 17 & 1266885 & 0,0915057 & 0,9084943 & 0,00001217 & 0,00000092 \\
\hline 18 & 1383506 & 0,0377761 & 0,9622239 & 0,00001886 & 0,00000024 \\
\hline
\end{tabular}

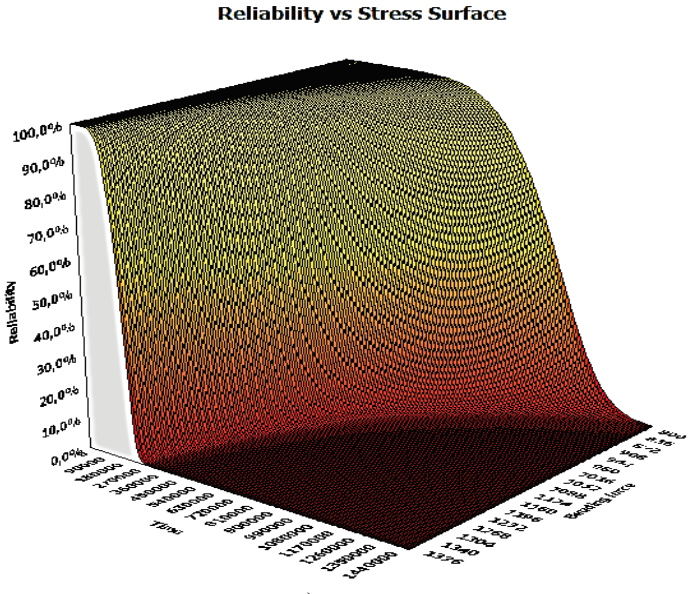

a)

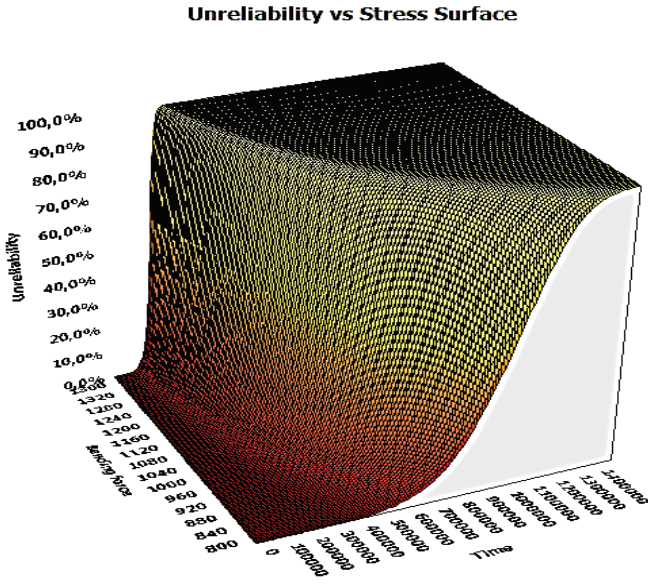

b)

Figure 9 Reliability parameters a) reliability function b) unreliability function

The main parameters are plotted using the ALTA 7 software program (Accelerated Life Testing Data Analysis). Reliability/Unreliability vs. time plot vs. stress provides reliability/unreliability values at a given time and time at a given reliability/unreliability and stresses (Figs. 9a and 9b). The instantaneous failure rate is a function of time and stress. A failure rate plot shows the expected number of failures per unit time at a particular stress level (Fig. 10a). A probability density plot represents the relative frequency of failures as a function of time and stress. Although the probability density plot is less important in most reliability applications it provides a good way of visualizing the distribution and its characteristics such as its shape and mode (Fig 10b). The mean number of cycles until failure in normal testing regime is determined using the mean relation for the IPL - Weibull relation and is 1002917 . The mean number of cycles until failure in normal testing regime can be determined also using the plot from Fig. 11 by marking a line through the mean number of cycles until failure for the 3 accelerated levels $(900 \mathrm{~N} ; 1100 \mathrm{~N}$ and $1400 \mathrm{~N})$. At the intersection of this line with the vertical line at the normal stress level of $800 \mathrm{~N}$, we find the mean life in normal testing regime. This plot (Life vs. Stress) 
demonstrates the effect of a particular stress on the life of the product. The mean number of cycles until failure of the blades in normal testing regime given by the manufacturer at their approval is 1000000 cycles, and the mean number of cycles until failure of the blades obtained after the accelerated tests was 1002917 cycles.

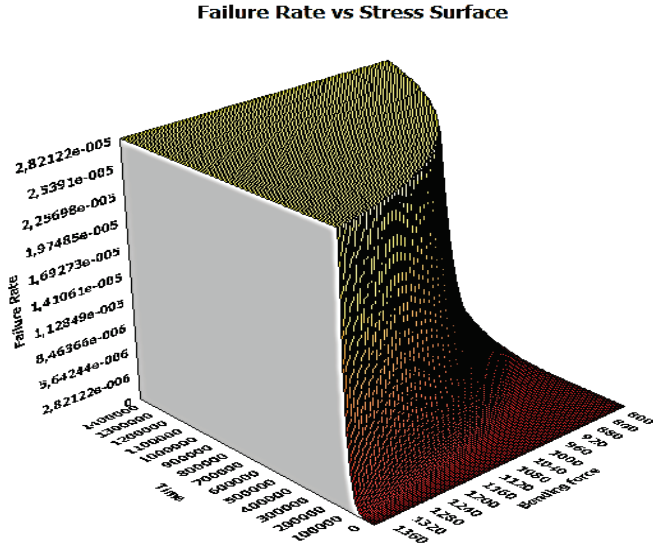

a)

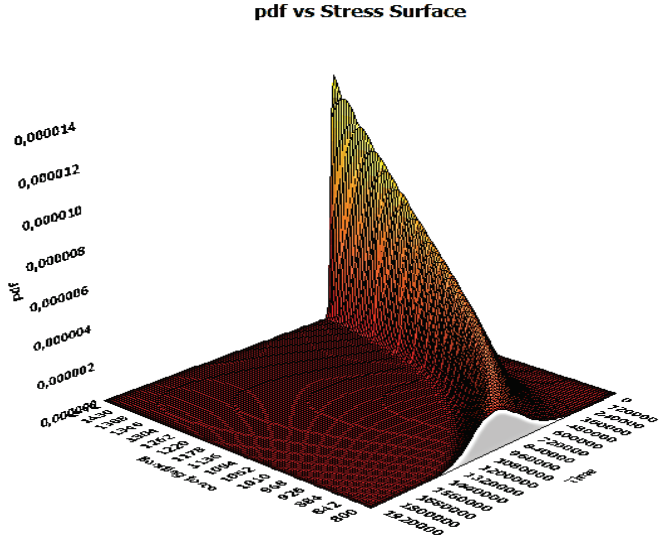

b)

Figure 10 Reliability parameters a) failure rate b) probability density function

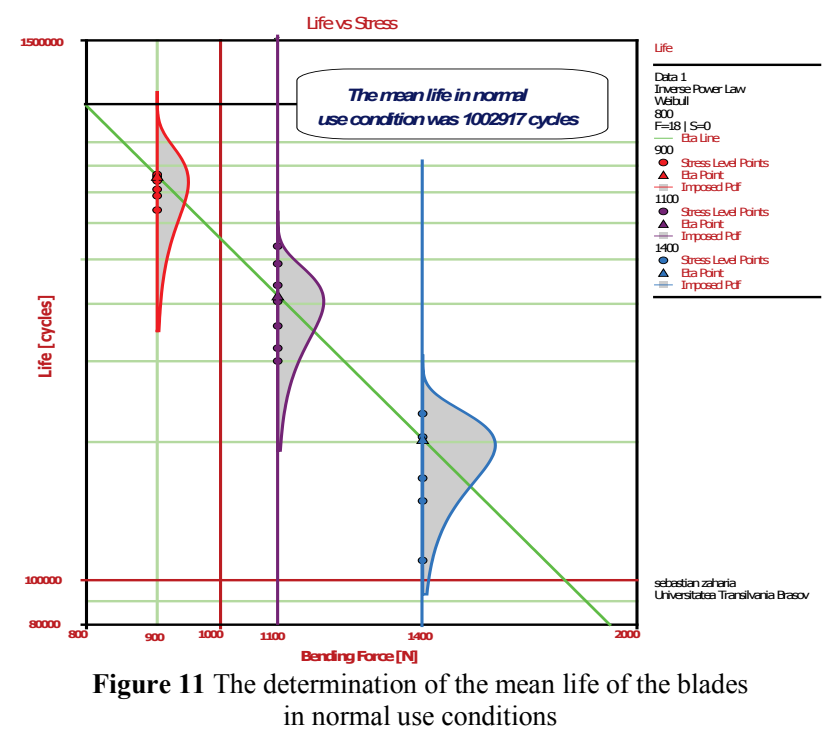

By adding the number of cycles until failure from accelerated tests, this is 8006246 cycles. By adding the number of cycles until failure in normal testing regime, this is 18047569 . The main purpose of accelerated testing realized on the blades from the structure of the Alouette helicopter, to reduce the number of cycles until failure using accelerated testing, was confirmed. By using accelerated testing on the Alouettte helicopter's blades, the number of cycles until failure was reduced by 2,25 times; this result entails also major reductions of the material costs. The testing in normal conditions of an 18blade batch costs about 10000 Euros and here the following is included: the costs associated with the analysis and the planning of the experiments; the costs regarding the realization of the experiments (material costs, the maintenance and the employees' payments); the costs regarding the statistical processing of the experimental data. Thus, by implementing the technique of the accelerated tests in the testing of the blades from the structure of the Alouette helicopter, the testing costs have been reduced to 4445 Euros, for the same batch of blades.

\section{Finite element analysis of the blade}

FEA is a sophisticated technique used by engineers to estimate the responses of structures and materials to environmental factors such as fluid flow, forces, heat and vibration. When we are planning an accelerated life test for a mechanical product, we must understand the failure mechanism we are trying to accelerate. Otherwise, we may choose inappropriate stresses or stress levels. A Finite Element Analysis is great for understanding these failure mechanisms [21].
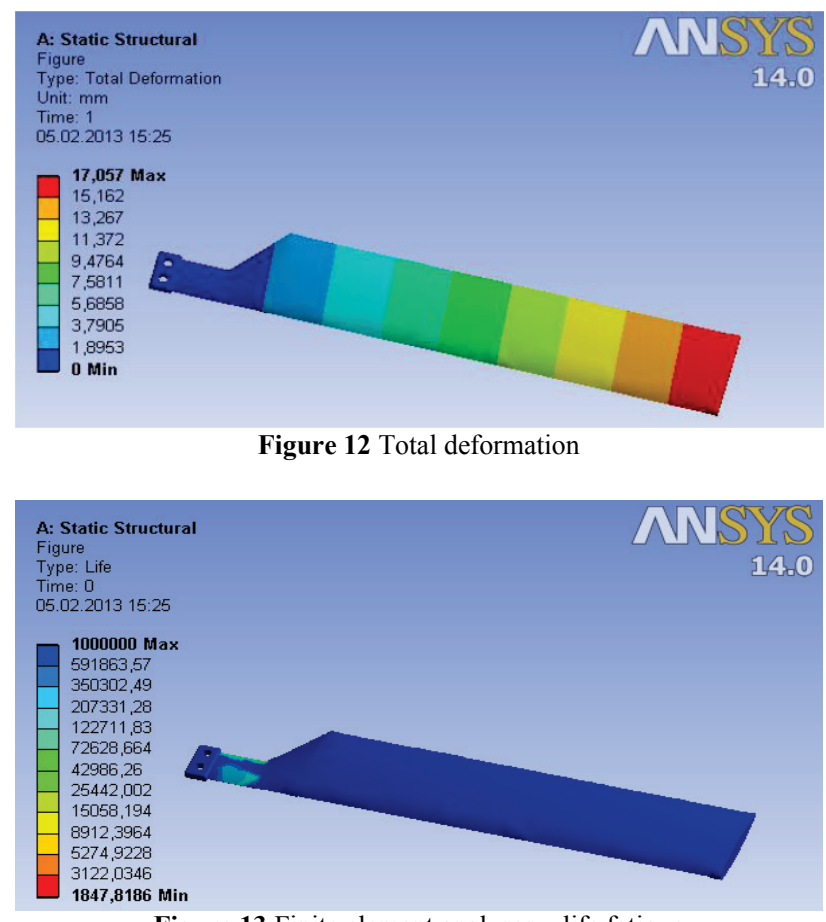

Figure 13 Finite element analyses - life fatigue

The model with finite elements is realized in the Ansys 14 software program. The stress was simulated by applying on the free end of the blade the forces from the third accelerated regime (the bending force at lagging $1400 \mathrm{~N}$; the bending force at feathering $300 \mathrm{~N}$; the axial force $32000 \mathrm{~N}$ ). The main purpose of the blade's analysis 
with finite elements is to validate the total deformations (Fig. 12) and the number of cycles until failure in accelerated testing regime (Fig. 13) occurred on the blade.

Thus, following the fatigue analysis with finite elements, we can deduce that the blade stressed at the most intense level will fail in the interval from 1847 cycles to 350000 cycles.

\section{Conclusion}

ART is an effective technology of demonstrating and improving product reliability in applications where the products are expected to perform for a long period of time. A basic goal of the ART technology is to describe what and how one can rapidly obtain objective and accurate initial information for accurate prediction of quality, reliability and other measurements during the product's design and manufacturing.

The management of the reliability accelerated tests represent a cumulation of activities performed to achieve the companies' objectives in an efficient manner by: the anticipation of the accelerated tests; the organization of the testing activity; the coordination of the accelerated testing techniques; the training and taking of important decisions concerning the testing methodology; the control and analysis of the experimental data resulting from the accelerated tests. Therefore, the management of reliability accelerated tests is a managerial process, the main element of every activity being the managerial decision, which has to be found in every stage of the product's development (design, manufacture, use).

In conclusion, in this paper we implemented the management process of reliability accelerated tests, by going through all the stages (the description of the testing device, the design of the experiments, the acquisition of data, the statistical analysis of the experimental data, analysis with finite elements and conclusions) necessary to the realization of correct tests (from a statistical and experimental standpoint). These techniques of accelerated testing, used in the aviation industry, determine a significant economic impact by reducing the testing time and the material costs associated with it.

\section{Acknowledgements}

This paper is supported by the Sectoral Operational Programme Human Resources Development (SOP HRD), financed from the European Social Fund and by the Romanian Government under the project number POSDRU/89/1.5/S/59323.

\section{References}

[1] Zaharia, S. M.; Martinescu, I. Reliability Tests, Transilvania University Press, Brasov, 2012.

[2] McLean, H. W. HALT, HASS, and HASA Explained: Accelerated Reliability Techniques. ASQ Quality Press, Milwaukee, 2009.

[3] Nelson, W. B. Accelerated Testing: Statistical Models, Test Plans, and Data Analysis. Wiley, New Jersey, 2004.

[4] Dodson, B.; Schawab, H. Accelerated Testing, A Practitioner's Guide to Accelerated and Reliability Testing. SAE International, Warrendale, 2006.
[5] Klyatis, L. M. Accelerated Reliability and Durability Testing Technology. Wiley, New Jersey, 2012.

[6] Yang, G. B. Life Cycle Reliability Engineering. Wiley, New Jersey, 2007. DOI: 10.1002/9780470117880

[7] Chiua, W. K.; Zhoua, Z.; Wangb, J.; Baker, A. Battle damage repair of a helicopter composite main rotor blade. // Composites Part B: Engineering. 43, 2(2012), pp. 739-753. DOI: 10.1016/j.compositesb.2011.07.014

[8] Ko, H. J.; Kim, Y. K. Reliability assessment of seat belt webbings through accelerated life testing. // Polymer Testing. 24, 3(2005), pp. 309-315. DOI: 10.1016/j.polymertesting.2004.11.005

[9] Woo, C. S.; Park, H. S. Useful lifetime prediction of rubber component. // Engineering Failure Analysis. 18, 7(2011), pp. 1645-1651. DOI: 10.1016/j.engfailanal.2011.01.003

[10] Bacharoudis, K. C.; Philippidis, T. P. A probabilistic approach for strength and stability evaluation of wind turbine rotor blades in ultimate loading. // Structural Safety. 40, (2013), pp. 31-38. DOI: 10.1016/j.strusafe.2012.09.006

[11] Toft, H. S.; Branner, K.; Berring, P.; Sørensen, J. D. Defect distribution and reliability assessment of wind turbine blades. // Engineering Structures. 33, 1(2011), pp. 171-180. DOI: 10.1016/j.engstruct.2010.10.002

[12] Li, H.; Hua Z.; Chandrashekhara, K.; Dua, X.; Mishra, R. Reliability-based fatigue life investigation for a mediumscale composite hydrokinetic turbine blade. // Ocean Engineering. $\quad 89$, (2014), pp. 230-242. DOI: 10.1016/j.oceaneng.2014.08.006

[13] Jang, Y. J.; Choi, C. W.; Lee, J. H., Kang, K. W. Development of fatigue life prediction method and effect of 10-minute mean wind speed distribution on fatigue life of small wind turbine composite blade. // Renewable Energy. 79, (2015), pp. 187-198. DOI: 10.1016/j.renene.2014.10.006

[14] Özsoy, S.; Çelik, M.; Suat Kadığlu, F. An accelerated life test approach for aerospace structural components. // Engineering Failure Analysis. 15, 7(2008), pp. 946-957. DOI: 10.1016/j.engfailanal.2007.10.015

[15] Orkisz, M.; Święch, Ł.; Zacharzewski, J. Fatigue tests of motor glider wing's composite spar. // Eksploatacja i Niezawodnosc - Maintenance and Reliability. 14, 3(2012), pp. 228-232.

[16] Shimokawa, T., Hamaguchi, Y.; Machida, S.; Ogawa, T.; Itabe, H. Statistical fatigue properties in the large strain region of a stainless steel sheet for use as an abrasion strip on helicopter rotor blades. // International Journal of Fatigue. 27, 3(2005), pp. 273-281. DOI: 10.1016/j.ijfatigue.2004.07.008

[17] Davies, D. P.; Jenkins, S. L.; Belben, F. R. Survey of fatigue failures in helicopter components and some lessons learnt. // Engineering Failure Analysis. 32, (2013), pp. 131151. DOI: 10.1016/j.engfailanal.2013.03.005

[18] Zaharia, S. M.; Martinescu, I.; Morariu, C. O. Life time prediction using accelerated test data of the specimens from mechanical element. // Eksploatacja i Niezawodnosc Maintenance and Reliability. 14, 2(2012), pp. 99-106.

[19] Navarro, P.; Aubry, J.; Marguet, S.; Ferrero, J. F.; Lemaire, S.; Rauch, P. Semi-continuous approach for the modeling of thin woven composite panels applied to oblique impacts on helicopter blades. // Composites Part A: Applied Science and Manufacturing. 43, 6(2012), pp. 871-879. DOI: 10.1016/j.compositesa.2012.01.020

[20] Yanga, C. L.; Sheua, S. H.; Yub, K. T. The reliability analysis of a thin-edge blade wear in the glass fiber cutting process. // Journal of Materials Processing Technology. 209, 4(2009), pp. 1789-1795. DOl: 10.1016/j.jmatprotec.2008.04.028

[21] Shahani, A. R.; Mohammadi, S. Damage tolerance approach for analyzing a helicopter main rotor blade. // Engineering Failure Analysis. 57, November (2015), pp. 56-71. DOI: 10.1016/j.engfailanal.2015.07.025 


\section{Authors' addresses}

Sebastian Marian Zaharia, PhD, Eng.

Transilvania University of Brașov,

Faculty of Technological Engineering and Industrial Management,

B-dul Eroilor, Nr. 29, Brașov, Romania

E-mail: zaharia_sebastian@unitbv.ro

\section{Prof. Ionel Martinescu, PhD}

Transilvania University of Brasov,

Faculty of Technological Engineering and Industrial Management,

B-dul Eroilor, Nr. 29, Brașov, Romania

E-mail: ionel_martinescu@unitbv.ro 